\title{
Seasonal Variation of Microalgae Diversity in Lake Abaya, Ethiopia
}

\section{Damtew Etisa*, Roman Nega and Woinshet Lule}

Microbial Biodiversity Directorate, Ethiopian Biodiversity Institute, Ethiopia

*Corresponding author: Damtew Etisa, Microbial Biodiversity Directorate, Ethiopian

Biodiversity Institute, P. O. Box 30726 Addis Ababa, Ethiopia, Email:

Research Article

Volume 2 Issue 5

Received Date: July 20, 2018

Published Date: August 09, 2018

demtewetisa@gmail.com

\section{Abstract}

This study evaluated the seasonal variations of microalgae species diversity in relation to some physico-chemical parameters in Lake Abaya for a period of three consecutive seasons (between July 2008 and August 2009). The aim was to relate the seasonal variability in the physico-chemical parameters of the lake to the abundance and diversity of microalgae. Nine sampling sites were established in the lake, and samples were collected once every season. Transparency and $\mathrm{pH}$ were measured in-situ using a water quality checker Water samples for microalgae abundance and species composition were analyzed at the Ethiopian biodiversity institute. In the laboratory, $\mathrm{pH}$ values in the lake ranged from 7.8-8.0, 7.7-9.0, 7.3- 7.4in rainy, post rainy and dry season respectively. The preserved Microalgae samples and the fresh water samples grow on liquid media (BBM and BG-11) were examined using binocular microscope and their identification to genus or species level were made on the basis of various descriptors of Microalgae. The result indicated that generally chlamydomonas is dominant species in all season and the most diversity in general was phylum Chlorophyta and Bacillariophyta phylum respectively in Lake Abaya.

Keywords: Microalgae; Season; Variation; Abaya Lake

\section{Introduction}

Aquatic environments are subject to high temporal variability, with frequent reorganization of the relative abundance and species composition of phytoplankton as a result of the interactions between physical, chemical and biological variables [1]. The microalgae community in a lake may vary both spatially and temporally [2]. The reduction in numbers or change in species composition of microalgae could lead to a reduction in zooplankton abundance [3]. Suggest that a number of factors limit microalgae growth in lakes and reservoirs. Factors such as water level, meteorological factors like solar radiation, photoperiod, rainfall, wind velocity, etc., and hydrological conditions (inflows and outflows) have great influence on the rate of primary production in lacustrine and flowing waters. The fertilizers applied on the agricultural lands with a view to boost crop yield eventually find their ways into nearby water bodies and pollute them [4]. There are numerous descriptions of the seasonal periodicity of microalgae communities and the possible factors controlling their periodic changes in fresh water lakes [3]. The diversity of a phytoplankton community can be used to characterize its structure. This structure is determined by the number of species present, their physiological properties and by the genetic potential of the organisms making up the community [5]. The seasonal fluctuations in microalgae abundance and species composition in any 


\section{International Journal of Oceanography \& Aquaculture}

water body is due to differential response of different species to changing levels of light, temperature, nutrients, grazing pressure, onset of parasitic infection, extracellular metabolites of plants and animals with a change in season during a course of year [6]. As demonstrate microalgae productivity follows essentially the same pattern in turbid as in clear waters except that the productivity profiles are compressed, due to the rapid attenuation of light. Blooms of blue-green algae are favored by the high temperature of the warmer months of the year $[7,8]$.

Lakes are one of humanity's most important resources, especially in the tropics, where they are often viewed as highly productive biological systems [9]. They are critical to the survival of local communities as they are the actual and potential sources of food and income. Furthermore, their range of variations in morphometry, physical and chemical features offers opportunities for superb comparative limnological studies. African lakes exhibit considerable seasonality related to alternations of warm, wet, cooler and dry seasons. Records of microalgae composition, assemblages and seasonal variations are quite few considering the size, peculiarity and importance of the lake and its biodiversity [10]. Ethiopia is rich in both natural water bodies such as rivers, lakes and reservoirs compared to other east African countries [10]. As the community vicinity mentioned Lake Abaya found in silte woreda and the water from the lake is the major source of drinking, swimming, washing and irrigation. Animals found in the Lake are Hippopotamus, fish, different flamingo and other birds around the lake. The Siltie Agriculture woreda taken 1250 koroso fish from Sebeta Research Center and inoculated to this lake. Microalgae (planktonic or suspended algae), one of the major biological components of aquatic ecosystems, play important roles in water bodies, not only as primary producers and hence as the base of food chains, but also as one of the dependable indicators of lake fertility and environmental changes [2]. In addition, microalgae are good indicators of environmental change due to their quick response to changes in environmental pressures such as nutrient availability [11]. They act as primary producers and represent themselves as a direct food source for other aquatic animals. They constitute the basic components of the aquatic food chain. Chemical and hydro-physical characteristics of water affect diversity and structure of the micro-algal communities of these lakes [12]. The seasonality of microalgae assemblages and their productivity in relation to environmental factors coupled with biological interactions have received attention [10,13] explained that many microalgae declines have occurred in tropical regions.
Phytoplankton dynamics is regulated not only by changing physical and chemical factors but also by biological factors such as grazing by zooplankton [14]. Most zooplanktons are phytoplankton consumers and thus contribute, along with other factors, to the reduction of phytoplankton numbers [5]. If its size is large, the zooplankton can be assumed to have a great influence on the phytoplankton community. Since each species of grazer has its own preference for particular food organisms, selection preference has an effect on the composition of the phytoplankton community. Those species of phytoplankton, which are not preferred as food by the zooplankton, are able to rapidly become dominant [15]. Microalgae represent the largest, yet one of the most poorly understood groups of microorganisms on earth. As happens with plants relative to terrestrial animals, microalgae represent the natural nutritional base and primary source of bulk nutrients in the aquatic food chain [16]. A large number of studies have been made on the community structure and primary production of microalgae in various East African lakes including those found in Ethiopia. In Ethiopia there are a lot of lakes and reservoirs. However, very few attentions have been given to the biodiversity of microalgae in the lakes, reservoirs and ponds of the country. Especially no studies reported on the seasonal variation of microalgae in Lake Abaya. Therefore, this study attempts to assess the seasonal variation of microalgae in Lake Abaya found. However, studies on seasonal variation of microalgae diversity in Lake Abaya still lacking. The aim of this study was to investigate seasonal pattern of microalgae variation by abundance of major groups with emphasis on the dominant microalgae species.

\section{Objectives}

\section{General Objective}

To investigate seasonal variation of the community structure of microalgae in relation to biological water quality in Lake Abaya, Ethiopia.

\section{Specific Objectives}

To assess the seasonal microalgae diversity with water quality of the Abaya lake, Ethiopia during the study period.

$>$ To investigate the taxonomic composition of microalgae.

$>$ To determine the frequency of major microalgae taxa over the study period.

$>$ To isolate and identify important microalgae species. 


\section{International Journal of Oceanography \& Aquaculture}

\section{Materials and Methods}

\section{Description of Study Site}

Lake Abaya is located at an altitude of $1828 \mathrm{~m}$ on the southern side of Siltie city found in SNNP between $038^{\circ} 22^{\prime} 18.4^{\prime \prime} \mathrm{E}$ and $07^{\circ} 56^{\prime} 27.4^{\prime \prime} \mathrm{N}$. It is found $748 \mathrm{~km}$ away from Addis Ababa. It covers 1250 hectares and 4-6m in depth. The land around the lake around 650 hectares is used for ecotourism. This research was conducted from July 2016 to May 2017 in three seasons. There were nine sampling sites, two inlets each with their own factor, two protected and free area, one wind below and long grasses local name called 'washabe', irrigation area (tomato, garlic, pepper, onion and etc.) and fish catching area. GPS was used to define the sites.

\section{Sampling Procedure}

Microalgae samples were collected seasonally with vials contain $50 \mathrm{ml}$ from selected site. The sites were selected based on human-induced pressures and topographic nature of Lake Abaya area. Site one was characterized by impacts of human and animal intervention. Site two was characterized by inlet or flooding, human and animal intervention. Site three was characterized by protected area which covered by forest around the site. Site four was characterized by fish catching area by local youth association on the shore line of the lake. Site five was characterized by animal intervention and tree planted. Site six was characterized by irrigation area and long grass called by local community 'kekebo'. Site seven was impacted by human who plant vegetable such as tomato garlic, pepper and potato and long grass which can cut the skin of person called by local community 'washabe'. Site eight was characterized by Inflow of flood and the dweller society waste induced impacts from their compound. The last site was characterized by bird flock animal dominate for the time being. The study sites were named as sites $1,2,3,4$, $5,6,7,8$ and 9 (table 1). Immediately after sampling, the samples collected from different plots with different factors were mixed in equal proportions to produce composite samples, which were used for determination of species composition and abundance. Microalgae samples were preserved with $4 \%$ formaldehyde in $50 \mathrm{ml}$ vials to study the variation of microalgae. The microalgae samples were examined with an inverted microscope and identification to genus or species level using taxonomic literatures available on phytoplankton [17-22].

For culturing on aerator by two different microalgae media type and conserve identified genera of microalgae from Lake Abaya in Ethiopian biodiversity institute gene bank after identification, the sample were collected with $35 \mathrm{ml}$ vials and immediately adding two different medias such as BBM (Bold Basol Medium) and BG $_{11}$ (Blue Green) medium to the samples and transported to Ethiopian biodiversity institute microbial laboratory.

\begin{tabular}{|c|c|}
\hline Site & Factors Considered During Sample Collection \\
\hline Site 1 & $\begin{array}{c}\text { characterized by impacts of human and animal } \\
\text { intervention }\end{array}$ \\
\hline Site 2 & $\begin{array}{c}\text { characterized by inlet or flooding, human and } \\
\text { animal intervention }\end{array}$ \\
\hline Site 3 & $\begin{array}{c}\text { characterized by protected area which covered } \\
\text { by forest around the site }\end{array}$ \\
\hline Site 4 & $\begin{array}{c}\text { characterized by fish catching area by local youth } \\
\text { association on the shore line of the lake }\end{array}$ \\
\hline Site 5 & $\begin{array}{c}\text { characterized by animal intervention and tree } \\
\text { planted }\end{array}$ \\
\hline Site 6 & $\begin{array}{c}\text { characterized by irrigation area and long grass } \\
\text { called by local community 'kekebo' }\end{array}$ \\
\hline Site 7 & $\begin{array}{l}\text { impacted by human who plant vegetable such as } \\
\text { tomato garlic, pepper and potato and long grass } \\
\text { which can cut the skin of person called by local } \\
\text { community 'washabe' }\end{array}$ \\
\hline Site 8 & $\begin{array}{c}\text { characterized by Inflow of flood and the dweller } \\
\text { society waste induced impacts from their } \\
\text { compound }\end{array}$ \\
\hline Site 9 & $\begin{array}{c}\text { characterized by bird flock animal dominate for } \\
\text { the time being }\end{array}$ \\
\hline
\end{tabular}

Table 1: factors considered during sample collection from Lake Abaya, Siltie.

Measurement of Physico-Chemical Parameters: Some physical parameters which were used for determination of seasonal variation and abundance of microalgae were measured in-situ. Secchi depth was estimated with a standard Secchi disc of $20 \mathrm{~cm}$ diameter. PH was measured by a portable digital $\mathrm{pH}$ meter.

Species Composition and Abundance of Microalgae: Major species of microalgae preserved with $4 \%$ formalin found in samples were identified. The microalgae samples were examined with an inverted microscope and identification to genus or species level was made on the basis of the various taxonomic literatures available on microalgae such as photo gallery of microalgae, freshwater key identification, different manuals and manuscript of different journals according to Gasse $\mathrm{F}$, Hindak F, Hindak F, Jeeji-Bai N, et al., Komarek J, et al. \& Whitford LA, et al. [17-22].

Statistical Analyses: To analysis data table, frequency, and percentage were used using Microsoft word 2013. 


\section{Results}

In this study, a total of 5 major phylum and nearly 42 genera of microalgae were identified from composite samples taken from the Lake. Namely, Cyanophyta (blue green algae), Chlorophyta, Bacillariophyta (Diatoms), Euglinophyta, and Charophyta were the most dominant phylum identified during the study period, of which 17 were Chlorophyta, 11 were blue green algae,10 were Bacillariophyta, 3 were Euglinophyta and 1 were Charophyta phylum. Season and the presence and absence of microalgae at the selected site.

\begin{tabular}{|c|c|c|c|c|c|c|}
\hline Taxa & \multicolumn{2}{|c|}{ S1 } & \multicolumn{2}{|c|}{ S2 } & \multicolumn{2}{|c|}{ S3 } \\
\hline Cyanophyta & Frequency & Percentage (\%) & Frequency & Percentage (\%) & Frequency & Percentage (\%) \\
\hline Aphanpcapsa & 10 & \begin{tabular}{|l|}
7.63 \\
\end{tabular} & 42 & 35.29 & 4 & 2.77 \\
\hline Cylindrospermopsis & 108 & 82.44 & 14 & 11.76 & 76 & 52.77 \\
\hline Nostoc & 13 & 9.92 & - & - & - & - \\
\hline Microcystis & - & - & 63 & 52.94 & - & - \\
\hline Merismopedia & - & - & - & - & 9 & 6.25 \\
\hline Oscillatoria & - & - & - & - & 5 & 3.47 \\
\hline Pseudanabaena & - & - & - & - & 37 & 25.69 \\
\hline Anabaena flos-aquae & - & - & - & - & 1 & 0.69 \\
\hline Chroococcus & - & - & - & - & 4 & 2.77 \\
\hline Gloeocapsa & - & - & - & - & 8 & 5.55 \\
\hline \multicolumn{7}{|l|}{ Chlorophyta } \\
\hline Chlamydomonas & 2479 & 92.87 & 10 & 55.55 & 23 & 9.31 \\
\hline Oocysts & 124 & 4.65 & & & 44 & 17.81 \\
\hline Selenastrum & 61 & 2.29 & - & - & 20 & 8.1 \\
\hline Volvox & 2 & 0.075 & - & - & - & - \\
\hline Scendesmus & 3 & 0.112 & - & - & - & - \\
\hline Cosmarium & - & - & 2 & 11.11 & 17 & 6.88 \\
\hline Scendesmus quadricauda & - & - & 6 & 33.33 & 19 & 7.69 \\
\hline Scenedesmus dimorphus & - & - & - & - & 9 & 3.64 \\
\hline Tetradron & - & - & - & - & 6 & 2.43 \\
\hline Monoraphidium & - & - & - & - & 54 & 21.86 \\
\hline Pediastrum & - & - & - & - & 1 & 0.4 \\
\hline Chlorella & - & - & - & - & 42 & 17 \\
\hline Chlorococcum & - & - & - & - & 1 & 0.4 \\
\hline Schroederia & - & - & - & - & 6 & 2.43 \\
\hline Pediastrum tetras & - & - & - & - & 1 & 0.4 \\
\hline Spinoclosterium & - & - & - & - & 3 & 1.21 \\
\hline Pediastrum simplex & - & - & - & - & 1 & 0.4 \\
\hline \multicolumn{7}{|l|}{ Bacillarophyta } \\
\hline Navicula & 6 & 0.34 & 70 & 17.11 & 155 & 20.53 \\
\hline Nitzschia & 1195 & 67.17 & - & - & 82 & 10.86 \\
\hline Melosira & 526 & 29.57 & - & - & - & - \\
\hline Aulocaseira & 4 & 0.22 & 233 & 56.97 & 242 & 32.05 \\
\hline Cyclotella & 36 & 2.02 & 63 & 15.4 & 113 & 14.97 \\
\hline Syndra & 12 & 0.67 & 43 & 10.51 & 9 & 1.19 \\
\hline Fragillaria & - & - & - & - & 7 & 0.93 \\
\hline Gyrosigma & - & - & - & - & 144 & 19.07 \\
\hline Cymbella & - & - & - & - & 1 & 0.13 \\
\hline Suririella robusta & - & - & - & - & 2 & 0.26 \\
\hline
\end{tabular}




\section{International Journal of Oceanography \& Aquaculture}

\begin{tabular}{|c|c|c|c|c|c|c|}
\hline Euglenophyta & & & & & & \\
\hline Euglena & 106 & 100 & - & - & - & - \\
\hline Phacus & - & - & 3 & 100 & 4 & 66.67 \\
\hline Phacus longcauda & - & - & - & - & 2 & 33.33 \\
\hline Charophyta & & & & & & 100 \\
\hline Closterium & - & - & - & - & 1 & 100 \\
\hline
\end{tabular}

Table 2: Diversity of Microalgae in Abaya Lake during 2017 seasonally with their frequency and percentage. Note: (-) shows absence of genera during study period.S1=Season 1, S2= Season, S3= Season3.

\section{Isolation of Microalgae Genera}

In the present study microalgae cultures were isolated from Lake Abaya. A total of 4 different genera (species) were isolated from all collected water samples. The isolated genera were identified as Chlamydomonas ovata, Chlamydomonas reinhardtii, Scenedesmus quadricauda and Anabaena based on their microscope identification and manuals (Figure 1).

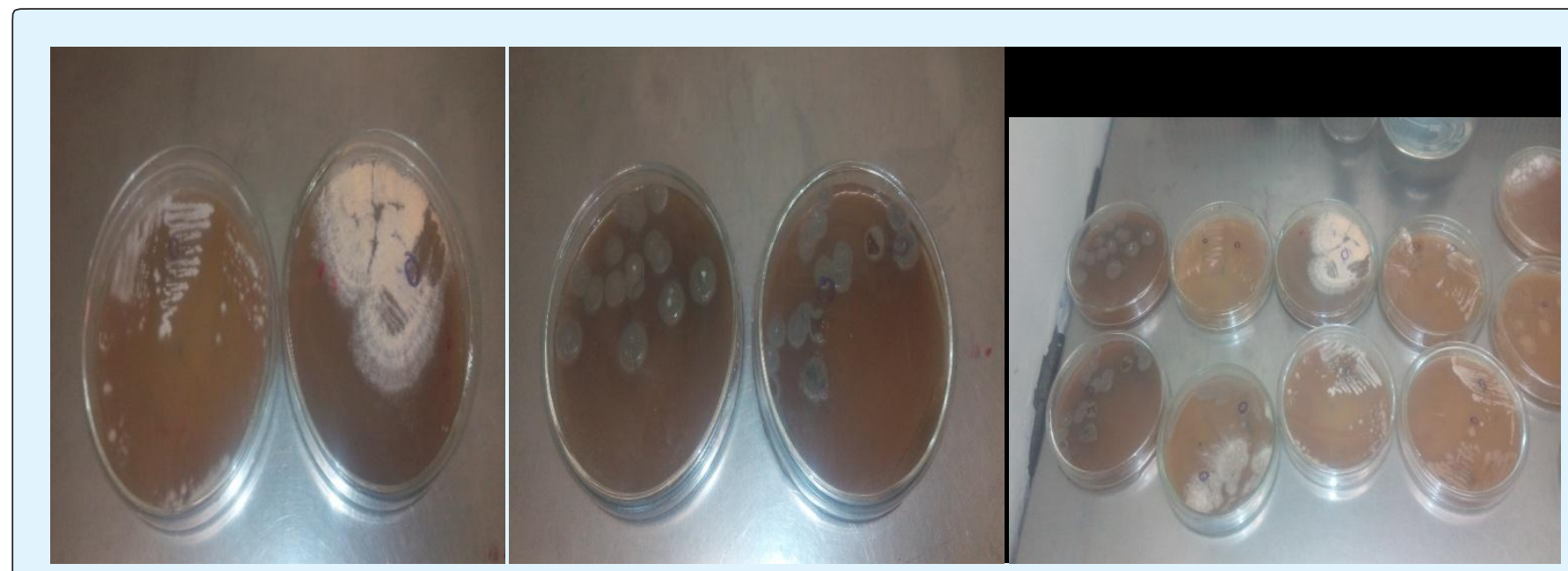

Figure 1: Pictures of some isolated microalgae.

\begin{tabular}{|c|c|c|c|}
\hline \multirow{2}{*}{ No } & \multirow{2}{*}{$\begin{array}{c}\text { Microalgae Genera and } \\
\text { species }\end{array}$} & $\begin{array}{c}\text { Media used for } \\
\text { culture }\end{array}$ \\
\cline { 3 - 4 } & & BBM & $\mathbf{B G}_{\mathbf{1 1}}$ \\
\hline 1 & Chlamydomonas ovata & + & - \\
\hline 2 & $\begin{array}{c}\text { Chlamydomonas } \\
\text { reinhardtii }\end{array}$ & + & - \\
\hline 3 & Scenedesmus quadricauda & + & - \\
\hline 4 & Anabaena & - & + \\
\hline
\end{tabular}

Table 3: Microalgae genera and species identified and conserved.

$+=$ Shows cultured on and $-=$ shows not cultured on the above identified genera and species were conserved in Ethiopian biodiversity institute gene bank.

\section{Transparency, pH and Altitude of the Lake}

At the time of sampling Lake Abaya transparency were found to be between $5 \mathrm{~cm}$ and $27 \mathrm{~cm}$. The highest measured Secchi depth was $27 \mathrm{~cm}$ during post rainy season while dry and rainy season had the lowest and second lowest Secchi depth $(26 \mathrm{~cm}$ and $11 \mathrm{~cm}$ respectively). The lake was found to be alkaline with $\mathrm{pH}$ ranging between 7.3 during dry season and 9.0 during post rainy season. The altitude was between 1816 and 1833 (Table 2).

\begin{tabular}{|c|c|c|c|}
\hline Season & Transparency & $\mathbf{p H}$ & Altitude \\
\hline Rainy & $8 \mathrm{~cm}-11 \mathrm{~cm}$ & $7.8-8.0$ & $1823-1833$ a.s.l \\
\hline Post rainy & $17 \mathrm{~cm}-27 \mathrm{~cm}$ & $7.7-9.0$ & $1816-1826$ a.s.l \\
\hline Dry & $5 \mathrm{~cm}-27 \mathrm{~cm}$ & $7.3-7.4$ & $1820-1826$ a.s.l \\
\hline
\end{tabular}

Table 4: Seasonal variation of Transparency, $\mathrm{pH}$ and altitude. 


\section{International Journal of Oceanography \& Aquaculture}

\section{Discussion}

The dominance of Chlorophyta and Diatom indicate it is indicators of good water quality and dissolved oxygen concentration and high enough to support aquatic life. This is true by author of Reynolds CS, et al. [1]. In terms of frequency the phylum obtained from all study period revealed that Bacillariophyta (2944 cells/count) distributed in highest proportion than Chlorophyta (2934 cells/count) and Cyanophyta (394 cells/count) respectively. The common Chlorophyta throughout the study season (period) were represented by Chlamydomonas (2512 cells/count), Bacillariophyta; Nitzschia (1277 cells/count) and Cyanophyta; Cylindrospermopsis sp. (198 cells/count). As previously strengthen by Fenta $A D$, et al. [23], variation of microalgae between lakes; is due to the difference in water quality, changes in physico-chemical characteristics of any water mass lead to concomitant qualitative and quantitative changes in microalgae organism. Therefore, the result investigated shows that Lake Abaya was characterized by eutrophic mainly as a result of high nutrient loading from surface runoff from around vicinity agriculture, vegetable, and concrete road constructed for community around the lake dweller. Over the first season of the study period Chlorophyta, Bacillariophyta, Cyanophyta and Euglinophyta were the four dominant phyla respectively $56.97 \%, 37.97 \%, 2.8 \%$ and $2.26 \%$ of the total abundances and variation of the study. This shows that it is almost similar with the study in Burullus Lagoon, in Egypt. Among the dominant phylum during the first study period was Chlorophyta highly dominate genera was Chlamydomonas sp. and Oocystis sp., respectively $92.87 \%$ and $4.65 \%$ and again similar with the study of Mohamed Z, et al. [24], between two small man-made lakes in Serdang, Selangor suggested that Chlorophyta was observed as most diverse phylum contributing $66.7 \%$ to total algal density (\%) in Seri Serdang Lake and $63.6 \%$ in Engineering Faculty Lake. From phylum Bacillariophyta /diatom group is second dominant phylum during the first study period and among the identified genera of Bacillariophyta highly dominant genera were Nitzschia and Melisora respectively $67.17 \%$ and $29.57 \%$. As investigate that Bacillariophyta remained dominant in the lake during winter because of they are able to grow under the condition of weak light and low temperature which are less suitable for other algae and low concentration of nutrients $\left(\mathrm{NO}_{3}-\mathrm{N}\right.$ AND $\left.\mathrm{PO}_{4}-\mathrm{P}\right)$ in the winter [25]. This study agreed with reports of diatom diversity and distribution in shallow lakes of Wapusk National Park (Manitoba, Canada) it shows that the most abundant taxa of the above lake are Nitzschia which is not common in other Eco zones by Jacques 0, et al. [26]. Therefore, the current findings are similar with that of Altaf $\mathrm{H}$, et al. \& Ganai $\mathrm{AH}$, et al. [25,27]. In the second study period the Bacillariophyta, Cyanophyta, Chlorophyta and Euglinophyta were dominant identified genera in Lake Abaya Siltie Zone. This shows that in the second period the nutrient which can used to make the bacillarophta's shell such as silica is loaded to the lake by around vicinity community farm and vegetable production by irrigation with the adaptability of diatom with low condition, weak light and low temperature. In third study period Bacillariophyta, Chlorophyta, Cyanophyta, Euglenophyta and charophyta respectively. The $\mathrm{pH}$ values varied between 7.3-9.0 in the lake. As the $\mathrm{pH}$ values showed, the lake was medium alkaline. It had been determined that the $\mathrm{pH}$ values varied between 6-9 in unpolluted lakes [28].

In this period Euglenophyta was found. It has been defined that Euglenophyta members existed more abundantly in polluted water and water that is reach in the organic mass [28]. In third season Bacillariophyta is dominant and among Bacillariophyta phylum Navicula, Cyclotella, Aulocaseira and synedra were present all season. This is similar with the study of which suggests Species of Cyclotella and melosira were indicator species in transition to eutrophy [29]. Only one general from Charophyta was found (Closterium). This species was found in few numbers in one month's (third months). The transparency of the lake water varies between $8 \mathrm{~cm}-27 \mathrm{~cm}$ almost turbid throughout the year. Surroundings of the lake covered with forest in one side and the other side are covered with different vegetables and papyrus grass therefore this might pollute the lake and descend the diversity of microalgae seasonally. Species of Cyclotella, Anabaena flos-aquae, Microcystis and Euglena caused water bloom in certain months. According to these properties Lake Abaya has eutrophic characterizes.

\section{Conclusions and Recommendations}

Present study shows seasonal diversity of microalgae in dry, followed by post rainy season and rainy season respectively due to variation in $\mathrm{PH}$, temperature and light intensity (transparency). In morphology there is great organization diversity from unicellular, colonial to filamentous. From this study, some information was gathered to determine the pollution levels based on the water properties and species diversities. Thus in a water body how this mechanic diversity occur is a matter of further study. There is a need to study the potential of robust microalgae in the future as the phytoplankton species diversity has a strong connection to the size of man-made freshwater lakes. Eco-restoration practices 


\section{International Journal of Oceanography \& Aquaculture}

shall be the better solution to preserve nature of water organism biodiversity. Because of fluctuation of nitrogen and phosphorous ratios play significant parts as limiting growth factors to most microalgae species/genera lake Abaya. Therefore, further study of Lake Abaya for nutrient availability is necessary.

\section{References}

1. Tarekgne Wondmagegne, Ayalew Wondie, Minwyelet Mingist, Jacobus Vijverberg (2012) Seasonality in Abundance, Biomass and Production of the Phytoplankton of Welala and Shesher Wetlands, Lake Tana Sub-Basin (Ethiopia). Journal of Water Resource and Protection 4(10): 877-884.

2. Adane Melaku (2017) Water Quality and phytoplankton community structure in the Southern Gulf of Lake Tana, Ethiopia. Addis Ababa University, Addis Ababa 1-99.

3. Rediat Abate (2008) Seasonal studies on phytoplankton in relation to some biological and physico-chemical factors in Lake hora-kilole, Ethiopia. Addis Ababa University, Addis Ababa 1-119.

4. Nigatu Ebisa (2010) Water Quality and Phytoplankton Dynamics in Geffersa Reservoir/ Ethiopia. Addis Ababa University, Addis Ababa 1-174.

5. Elber F, Schanz F (1989) The cause of change in the diversity and stability of phytoplankton community in small lakes. Freshwater boil 21(2): 137-251.

6. Adon Marie Paulette, Ouattara Allassane, Gourene Germain (2011) Seasonal variation in the diversity and abundance of phytoplankton in a small African tropical reservoir. Afr J Microbiol Res 5(18): 26162626.

7. Johan U Grobbelaar (1985) Phytoplankton productivity in turbid waters. Journal of Plankton Research 7(5): 653-663.

8. Zelalem D, Demeke K (2014) The Study of Temporal Dynamics of Phytoplankton Biomass and Species Composition in Relation to Some Physical and Chemical Factors, Lake Kuriftu, Oromia Region, Ethiopia. Fish Aquac J 4(1): 1-17.

9. Zelalem DF (2013) Phytoplankton biomass and species composition in relation to some physical and chemical characteristics of Lake Adale, Haramaya
Woreda, Oromia Region, Ethiopia. Limnological Review 13(2): 87-92.

10. Ayalew Wondieand Akoma, Osondu C (2010) Hydrobiological Survey of the Bahir Dar Gulf of Lake Tana, Ethiopia. African Research Review 4(2): 57-70.

11. Reynolds CS (2006) The Ecology of Phytoplankton. Cambridge University Press, Cambridge.

12. Hanan M Khairy, Kamal H Shaltout, Mostafa M ElSheekh, Dorea I Eassa (2015) Algal Diversity of the Mediterranean Lakes in Egypt. International Conference on Advances in Agricultural, Biological \& Environmental Sciences 22-23.

13. Dilnessa Gashaye (2016) Spatial and temporal phytoplankton species diversity in Southern Gulf of Lake Tana, northwestern Ethiopia. IJBC 8(10): 224232.

14. Graneli E, Carlsson P (1999) Effects of N:P:Si ratios and zooplankton grazing on phytoplankton communities in the northern Adriatic Sea. 11. Phytoplankton species composition. Aquat Microb Ecol 18: 55-65.

15. Wetzel R G (2001) Limnology: Lake and River Ecosystems. $3^{\text {rd }}$ (Edn.), Academic Press NY, pp: 1006.

16. Catarina Guedes, Xavier Malcata F (2012) Nutritional Value and Uses of Microalgae in Aquaculture. Aquaculture 1-21.

17. Gasse F (1987) African wetlands and shallow water bodies. burgis MJ, Symoens JJ (Eds.), ORSTOM, Paris. GMBH, Italy, pp: 759.

18. Hindak F (1992a) Several interesting planktonic Cyanophytes. Algological studies 66: 1-15.

19. Hindak F (1992b) On the taxonomy of the genus Merismopodia and related genera (Cyanophyta). Algological studies 67: 3-19.

20. Jeeji-Bai N, Hegewald E, Soeder CJ (1977) Revision and taxonomic analysis of the genus Anabaenopsis. Arch Hydrobiol 51: 3-24.

21. Komarek J, Anagnostidis K (2005) Cyanoprokaryota: 2. Teil: Oscillatoriales. In: Büdel B (Eds.), Süßwasserflora von Mitteleuropa, Elsevier $\mathrm{GmbH}$, München 19 (2): 1-759. 


\section{International Journal of Oceanography \& Aquaculture}

22. Whitford LA, Schumacher GJ (1973) A manual of freshwater algae. Sparks Press, Raleigh, NC, pp: 324.

23. Fenta AD, Kidanemariam AA (2016) Assessment of Cyanobacteria Blooms Associated with Water Quality Status of Lake Chamo, South Ethiopia. J Environ Anal Toxicol 6: 343.

24. Mohamed Z Nassar, Hamdy R Mohamed, Hanan M Khiray, Sarah H Rashedy (2014) Seasonal fluctuations of phytoplankton community and physico-chemical parameters of the north western part of the Red Sea, Egypt. Egyptian Journal of Aquatic Research 40(4): 395-403.

25. Altaf H Ganai, Saltanat Praveen (2014) Effect of physico-chemical conditions on the structure and composition of the phytoplankton community in Wular Lake at Lankrishipora, Kashmir. Int J Biodivers Conserv 6(1): 71-84.
26. Jacques O, Bouchard F, MacDonald LA, Hall RI, Wolfe $\mathrm{BB}$, et al. (2016) Distribution and diversity of diatom assemblages in surficial sediments of shallow lakes in Wapusk National Park (Manitoba, Canada) region of the Hudson Bay Lowlands. Ecol Evol 6(13): 45264540 .

27. Ganai AH, Parveen S, Khan AA, Maryam H (2010) Phytoplankton diversity at Watlab Ghat in Wular Lake, Kashmir. Jour Eco Nat Environ 2(8): 140-146.

28. Elif E, Arif G (2003) Study on the Phytoplankton and Seasonal Variation of Lake Simenit (Terme - Samsun, Turkey). Turk J Fish Aquat Sci 3: 29-39.

29. Round FE (1956) The Phytoplankton of their water supply reservoir note Central Wales. Arch F Hydrobiol 220-232. 